\title{
Editorial
}

\section{River ecological restoration across frontiers}

This special thematic set of Knowledge and Management of Aquatic Ecosystems is a part of the proceedings of the 7th SER European conference on ecological restoration ((http://www.seravignon2010.org/) which was held for the first time in France in the prestigious premises of the Palais des Papes International Conference Center in Avignon from 23 to 27 August 2010. The theme chosen "Ecological Restoration and Sustainable Development: Establishing Links Across Frontiers" is at the core of environmental concerns in Europe. More than 200 oral presentations were delivered in 64 sessions, including 8 special sessions and 4 workshops. 102 posters were also on display. 8 plenary speakers gave us the benefit of their experience and 9 mid-field trips were organised to enable participants to see specific examples of restoration or ecological restoration projects in the Provence-Alpes-Côte-d'Azur Region. Of course, for this year of 2010 , this congress on ecosystem restoration was particularly dedicated to biodiversity restoration.

Biological conservation and ecological restoration of habitats are both essential in Europe. The aim of the conference was to present and assess the state-of-the-art in ecological restoration and to bring together scientists, policy makers, practitioners and stakeholders for mutual exchange and synergy. It has been also the opportunity for transboundary contacts and exchanges of knowledge, experiences, and "best" or at least successful practices in ecological restoration, an emerging field and profession at the crossroads of applied ecology, ecological and environmental economics. Restoring and improving the ecological health and sustainability of habitats, ecosystems, ecosystem services, and landscapes in Europe is a major challenge, particularly in the face of increasing pressures due to global changes including land use, demography, socio-economic, and climate changes.

The four papers presented in this special issue were presented in parallel sessions dedicated to "restoration of rivers and riparian ecosystems" and in a special session dedicated on the "future of the best ecological practices and sustainable management in European Atlantic rivers". This special issue is completed at the European level by the publication of special issues in two other international scientific journals (Ecologia Mediterranea, 37, 2011 and Applied Vegetation Science in 2012).

In this four papers, spatial scales were emphasized and will be surely better integrated in river restoration ecology in the future: Bejarano and Sordo-Ward show the importance of biogeographical comparison (Boreal vs. Mediterranean) and constraint for riparian shrubby vegetation in regulated rivers, when Aguiar et al. presented the importance of having GIS tools for restoring riparian vegetation at the landscape scale in Portugal. Horreo and Vasquez et al. show the importance of considering a keystone species, Atlantic salmon populations, in ecological restoration of rivers in their southern biogeographical edges (Asturias, NorthWestern Spain). The survey of this migratory species, living across frontiers, is very important for river restoration as a way to evaluate the good ecological statute of restored rivers. Evaluation of ecological restoration is a key to future progress, and comprehensive evaluations are rare (Suding, 2011). Most of the contributors of this special session on "future of the best ecological practices and sustainable management in European Atlantic rivers" are implicated in the European Interreg IVb program called Atlantic Aquatic Resource Conservation (AARC: http://aarcproject.org/). It was also important to notify the representation of several taxonomic groups concerned by restoration ecology research or applied programs in river restoration (fish, crayfish, butterfly, terrestrial and aquatic flora, invertebrates, etc were cited). These ecological and biological surveys were usually related to physical restoration and/or landscape management (e.g. importance of linking farming systems in river restoration). It gave us also a large panel on aquatic habitats/species 
restoration. Having sessions on Atlantic rivers joined with Mediterranean river restoration constraints as in the special session called "Sustainable management and restoration of Mediterranean riparian zones: the importance of International cooperation" was an achievement of this 7th European chapter of the Society for Ecological Restoration SER International as it permits exchange of experiences.

We can conclude that the future best practices in river restoration ecology will be concerned by spatial scales, less-studied taxa (such as bryophytes), as for example in the paper of Hugonnot (2011) in the other SER special issue of ecologia mediterranea, and more comparisons across frontiers.

The 7th SER European conference on ecological restoration could not have been held without the support of the Mediterranean Institute of Ecology and Palaeoecology and the University of Avignon, co-organizers of this conference. Numerous partners contributed to making it possible : research institutes (CNRS - INEE - National Center for Scientific Research -, IRD Research Institute for Development, IUT - University Institute of Technology of Avignon, Paul Cézanne University, Provence University), local authorities (Region of Provence-Alpes-Côte d'Azur, General Council of Vaucluse, DREAL - PACA - Regional Department for the Environment Provence-Alpes-Côte-d'Azur), private foundations (MAVA, Tour du Valat), NGO (WWF, and private companies (GRT Gaz, CDC - Biodiversité, Gagneraud Constructions, EcoMed, Naturalia Environnement). In addition to institutional support, a large number of people acting in an individual capacity devoted a good deal of time and energy to making a success of the conference. We are deeply grateful to the members of the organizing committee and of the scientific committee, the organizers of field trips, the student volunteers, the managers of the Palais des Papes International Conference Center and the University of Avignon for their support and enthusiasm. And finally, thanks to all the contributors to this conference and to all the participants who by their presence made it such a success.

\section{REFERENCES}

Hugonnot V., 2011. Bryophytes and bryocenosis of Entraygues site (Var, France) as a tool for evaluating a hydrologic renaturation project. Ecologia Mediteranea, 37, 45-56.

Suding K., 2011. Toward an era of restoration in ecology: successes, failures, and opportunities ahead. Annu. Rev. Ecol. Evol. Syst., 42, 465-487.

I. Bernez

UMR 985 Ecologie \& Santé des Ecosystèmes INRA-Agrocampus Ouest 65 rue de St. Brieuc, 35042 Rennes Cedex

France

T. Dutoit

Université d'Avignon IUT

UMR CNRS IRD IMEP

Site Agroparc BP 61207, 84911 Avignon Cedex 09

France 